\title{
Developing A Thinking Strategy of Understanding Numeracy Among Students of $\mathrm{SDH}$
}

\author{
Siti Rahaimah Ali, Zuria Farhana Muhamad, Syaza Zaini, Nur Bahirah Badarudin
}

\begin{abstract}
The article describes the process of developing as well as evaluating the effectiveness of module in identifying levels of numeracy understanding among students in School for Hospitalized Children (SDH). The development process involves the preparation of materials, expert review and content evaluation of the module. During the development process, the module is reviewed by four experts from numerous field of study. Some suggestions has been identified and improvements has been made based on the suggestions provided. The refined module was assessed for accuracy by 20 evaluators, consisting of four experts from the same field of study and 16 SDH teachers. The results showed that the development of modules that were based on needs analysis, theory, literature review and curriculum review plays vital roles in producing a comprehensive module. All the information collected has led to the establishment of more knowledge-based modules. In general it was found that; needs analysis is necessary in order to produce modules that can be used by teachers, the process of developing modules should take into consideration on the combination of several theories in order to produce a comprehensive knowledge-based module, literature review also provides important information in producing child-centered learning activities, curriculum review is crucial in creating teaching and learning activities that meet the curriculum objectives finally, the results of the expert review from various fields of study have provided a wealth of information in theory and practice. Module assessments performed by both experts and users are also essential in producing modules that are well-researched and user-friendly
\end{abstract}

Keywords: Module on numeracy understanding, Numeracy, School for Hospitalized Children.

\section{INTRODUCTION}

I In line with UNESCO's missions to provide education for all as well as to achieve sustainable in educational perspective, Malaysia has created another dimension in national education by establishing School for Hospitalized Children (SDH),

Revised Manuscript Received on October 10, 2020.

* Correspondence Author

Siti Rahaimah Ali*, Pedagogy Department, Human Development Faculty,Universiti Pendidikan Sultan Idris (UPSI)., Tanjung Malim, Malaysia.Email: siti.rahaimah@gmail.com

Zuria Farhana Muhamad, Mathematics Department, Faculty of Science and Mathematics, Universiti Pendidikan Sultan Idris (UPSI)., Tanjung Malim, Malaysia. Email: zuriafarhana36@gmail.com

Syaza Hazwani Zaini, Department of Educational Studies, Faculty of Human Development, Universiti Pendidikan Sultan Idris (UPSI). Tanjung Malim, Malaysia. Email: syaza@fpm.upsi.edu.my

Nur Bahirah Badarudin, General Education Department, Kolej Vokasional Port Dickson, Negeri Sembilan, Malaysia. Email: nurbahirahbadarudin@gmail.com

(c) The Authors. Published by Blue Eyes Intelligence Engineering and Sciences Publication (BEIESP). This is an open access article under the CC BY-NC-ND license (http://creativecommons.org/licenses/by-nc-nd/4.0/) aimed to ensure that regardless of circumstances, educational services are accessible to all students whom receiving treatment in the hospital ward. The establishment of SDH is a collaboration between the Ministry of Education Malaysia (MOE), Ministry of Health Malaysia (MOH) and Non-governmental Organizations (NGOs) with one purpose which is to provide education to students in hospitals who are prepared to learn. According to the "Education for All (EFA)" principle outlined by The United Nations Educational, Scientific and Cultural Organization (UNESCO), every child, adolescent and adult should be provided with basic education. One of the six (6) internationally recognized educational goals are, "Ensuring that by 2015 all children, particularly girls, children in difficult circumstances and those belonging to ethnic minorities, have access to, and complete, free and compulsory primary education of good quality ". Learning session at school in hospital should be fun and flexible as it can lead to a conducive environment for children to acquire knowledge. It is indirectly a therapy that can help the process of recovery from health problems that student is suffering from. Thus, in order to encourage school in hospital teachers to implement more creative and innovative teaching and learning (PdPc), a more effective numerical reasoning strategy should be produced, at the same time this will allow students to know their respective levels of numeracy. This thinking strategy emphasizes multi-grade learning and teacher-led instruction as a facilitator. Learning is oriented towards self-directed, self-accessed, self-paced and self-assessed methods. In line with this, to achieve the aspirations of the Malaysian Education Plan 2013-2025 through the first shift by providing equal access to international quality education also supported UNESCO's goals. Malaysia has taken various initiatives to expand access and equity of education as well as improve the quality of education, in line with the Minister of Education speech in UNESCO Malaysia Day 2013; "Through the Malaysian Education Development Plan (PPPM) 2013-2025, I will ensure that quality education is provided to all students regardless of grade and background." Therefore, a method of learning and evaluation especially in enhancing the elements of "thinking strategy" is essential in numeracy as well as focusing on 21st century skills. Thus, a thinking strategy based on the Numerical Understanding Model (MPKN) developed by Siti Rahaimah (2014) need to be applied so that teachers can determine their students' understanding of numeracy and have fun and conducive learning session.

Published By:

Blue Eyes Intelligence Engineering

\& Sciences Publication

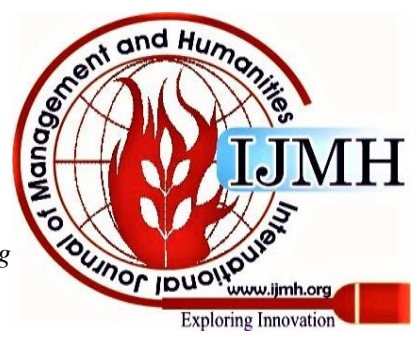


The objectives of this study were to identify the level of numeracy comprehension among SDH students, develop the numeracy comprehension strategy among SDH students according to the numerical comprehension level and evaluates well as validate thinking strategies among SDH students' numeracy regardless of the situation and place which includes students receiving treatment in hospital ward. This research method uses experimental quasi where it involves a pre-test and post-test to obtain data on the level of numeracy understanding among SDH students and assessment strategies. This study involves two main phases which is identifying the level of numeracy comprehension among SDH students (intensive literature review, questionnaires and interviews with coordinator / specialist teachers / hospitalists) and developing strategies for thinking numeracy understanding of SDH student numeracy based on numerical comprehension level (characterization of numeracy comprehension level by MPKN) and assess and validate numeracy comprehension strategy of SDH students by conducting workshops with SDH teachers. The results of this research are expected to propose a numeracy comprehension thinking strategy among SDH students in order to produce students with high order thinking skills (HOTS), soft skills and self-directed learning and to identify the level of numeracy comprehension among students in $\mathrm{SDH}$ in terms of numeracy understanding. This study is a prelude in applying PRGS, which is to build a numerical understanding strategy model for students receiving treatment in SDH throughout Malaysia.

\section{PROBLEM STATEMENT}

$\mathrm{SDH}$ is the only school designed to help children who are receiving treatment to undergo teaching and learning process so that they are not to be left out like other children. In Malaysia there are $15 \mathrm{SDHs}$ to incorporate learning for children during treatment. In SDH, students learn according to a predefined schedule and use the same curriculum as the mainstream which makes it difficult for teachers to identify the understanding level of SDH students especially in mathematics. In short, there is no single thinking strategy used to determine the level of numeracy comprehension for SDH students. Therefore, in order to facilitate the assessment of SDH teachers in determining the level of numeracy comprehension among SDH students, an understanding thinking strategy is necessary for these students to think and learn in exciting environment. Therefore, we can produce a generation with high problem solving skills even when these students are in treatment. The level of thinking strategy for numeracy can be seen in many positive aspects based on student's personalities. However the level of understanding of numeracy is a very complex process. Goldin (1992: 275) explains, “... Problem solving involves a highly complex aggregate of internal psychological processes, which may include verbal and syntactic processing; representation; the use of a variety of complex heuristics; conceptual understanding; a variety of affective responses; metacognitive processes; belief systems about mathematics...". Some mathematical problem solving models have been proposed by mathematics education researchers such as Polya (1957), Davis (1984), Schoenfeld (2002), Krulik and Rudnick (1996). The KBSM (PPK, 2011) and KSSM (PPK, 2012) certainly emphasize the above skills.
Since KBSM was implemented, teachers have been encouraged to use Polya's problem solving model (1974). Even though a lot of research has been conducted, students still unable to possess good problem solving and reasoning skills (Siti Rahaimah, 2016; TIMSS, 1999-2011; PISA 2009; Nor'ain et al. 2011a, 2011b, Zarimah, 2011, Parmjit \& Lau, 2006). For example, analysis of the Trends in International Mathematics and Science Study (TIMSS) report (2011), showed that Malaysian students' achievement in mathematics education experienced a sharp decline between 1999 and 2011. Specifically, there are three dimensions showed that student achievement was not satisfactory which are knowledge (35\%) questions, application (40\% questions) and reasoning (25\% questions). The details of student performance also indicate that only $2 \%$ to $10 \%$ of students reach a high level. At this point students are not able to handle information, make conclusions and generalizations as well as solve complex problems. This provides an indication that our students only understand the basic concepts but generally unable to apply that knowledge in practical (MOE, 2012). Therefore, in order to achieve Malaysian Education Development Plan (PPPM) 2013-2025 aspiration, Malaysian education system needs to provide greater performance improvement based on international education benchmarks in line with international standards (PPPM, 2012). These improvements include standards for the field of Mathematics and focuses more on 21st century skills such as problem solving and reasoning skills. Therefore, improvements need to be made to ensure long-lasting high performance of education system in our country in developing the element of purity and competence that students need to succeed and thrive in an increasingly globalized world. Therefore, this research is designed based on Numerical Comprehension Thinking Strategies in solving mathematical problem for students receiving treatment in SDH throughout Malaysia. Thinking strategy is divided into 4 stages which are de-coding, meaning-making, application and analysing. Each of these stages has specific characteristics that determine students understanding of numeracy. In hope that this project will be able to produce students with higher order thinking skill while receiving hospital treatment.

\section{LITERATURE REVIEW}

The numerical understanding model consists of four stages namely de-coding, knowledge-making, application and analysing (Luke and Freebody, 2009) adapted by Siti Rahaimah (2014). As numerical understanding, teaching and learning processes are complex (Ball, 2002; Kilpatrics, Swafford and Findell, 2001), this project focuses only on developing numerical comprehension thinking strategies based on critical numerical research models (Jane Watson, 2008). This numeracy understanding thinking strategy emphasizes on several key elements in developing numeracy understanding among SDH students, including providing students with an opportunity to understand numeracy concepts and understand context before venture into more complex thinking.

Published By:

Blue Eyes Intelligence Engineering \& Sciences Publication 
Secondly, it provides an opportunities for exploration with others such as pairs, groups or whole-class discussions where different views can be gathered. Thirdly, it give students the opportunity to create something that applies from new knowledge that they had gained,especially explaining their results to peers and in preparation for answering questions in exam. According to Ornstein and Hunkins (2004), learning cannot be separated from children's daily life, but learning must be based on children's needs and interests. This is in line with the implementation of the School in Hospital program which gives children the opportunity to continue gaining knowledge despite facing their health problems. The teaching and learning process of SDH has been modified to fit the child's circumstances and to meet their needs as students.

Therefore, through this numerical understanding thinking strategy students are able to draw on ideas and relate to each other to solve the problems given.This numerical understanding thinking strategy can also serve as a checklist for teachers and students to see the insights that individuals have implemented, to explore types of thinking skills, and to enable students to analyse the given questions. This numerical understanding thinking strategy makes it easier for students to express their thinking and adapt it to everyday life. A checklist for both students and teachers with questions on types of thinking skills do we have; do we need to explore other types of thinking skill and what happens if we analyse the question. This strategy makes it easy for students to use so that everything that comes to mind can be written in stages as shown in the model of numerical comprehension. Through this model, each discussion is not just a re-coding, but through this model each idea has its own level and each idea can be categorized according to the stages in the numerical comprehension model. Through this level of numeracy understanding thinking strategies, students can reflect from various strategies used in the given stages Students need to be familiar with this stage and it does takes time for them to adapt, but eventually it will become a habit Students can also use this numerical model in other subjects. This is supported by the Harvard Zero Project (2010), in which it proposed to develop student understanding during and after activities which students can be asked to reflect their thinking skills with questions such as; what numerical ideas would you like to know more about the outcome of this investigation. The difficulties in identifying the steps and onwards for developing student understanding is clearly visible (Watson, Callingham \& Donne, 2008a). Numeracy involves different ways of solving problems. There is not just one way to get the right answer. Students find it useful to discuss the types of strategies they use in their real life. By implementing this strategy, it has boosted student's confidence and it was convinced that there was only one way to perform the process in numeracy. For each numerical question, the solution according to the numerical model needs to follow the procedure and the stages of practical knowledge. This makes it easier for students to find answers to any questions. The model's framework also coincides with learning using constructivist approach, whereby new knowledge is related elates to what they already know, builds their own understanding, and creates new meanings. This approach can help students to recognize numerical features in daily life (Gal 2002).
Based on this numerical understanding thinking strategy framework, students are able to develop their own thinking strategies according to situations, eventually, it will also enhance their intelligence as they can make decisions in every aspects of their life. The strategy itself can act as a transformative tool for teachers rather than teaching using traditional method. However, in terms of learning numeracy, more practiced is needed in both learning and teaching to ensure that they obtain the necessary skills for future used.

This strategy can also help students to build and understand numerical concepts. Students create their own ideas and knowledge that will lead to the creation of new ideas. Through this numerical strategy framework, students' previous knowledge can be identified by using early exploration, brainstorming, challenging questions, quizzes and questions that encourage students to think. Teachers play an important role in the classroom as they need to investigate students' early understanding by exposing them to activities that encourage concentration by combining current and previous knowledge that students' had already acquired This can be done by raising some questions, giving them some case studies that required them to think, explore some different phenomena and asking them to contribute ideas.

This level of numeracy understanding strategy framework, in turn, can generate deeper numerical ideas based on topics in mathematics. Students are given a few examples of self-help questions which will help students familiarize themselves with de-coding and meaning-making, then proceed to the next stages of application (using), and analysis (Luke and Freebody, 2009). In short, by using this model, it can also help students to apply their own understanding creatively to solve questions. Numerical comprehension strategy thinking is adapted from the Numerical Understanding Level Model which includes the following stages of numeracy comprehension:

\section{Stage 1: De-coding}

In this stage, de-coding are used to ensure that students state the mathematical terminology used, for example students can state the basis of calculation which are plus, subtract, multiply and divide and students also be able to state the terminology in terms of numbers, measurements, fractions, geometric shapes etc. At this level, students can also list the terms, ideas, languages and all mathematical information and adapt them in the form of concept maps. At this stage, students learn vocabulary for all numerical information. For example, geometry students can recognize a given shape, draw a shape and recreate it to form an object (Noraini Idris, 2005) in which all information and mathematical terms will be collected then categorize it into mathematical concepts (Rivalland, 2000). After identifying mathematical concepts, students are able to recognize diagrams by looking at the whole entity of objects without knowing the features. For example, geometric concepts are viewed as whole entities rather than their components or properties.

Published By:

Blue Eyes Intelligence Engineering

\& Sciences Publication

(C) Copyright: All rights reserved.

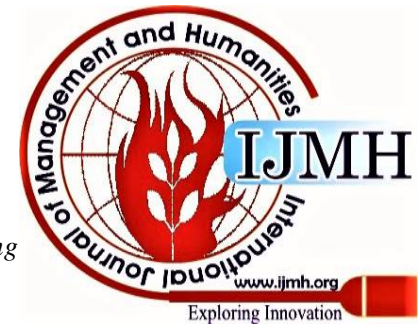



is the physical shape of the diagram and not the component or nature of the shape. Through this process students will contribute ideas to various perspectives on numeracy. This can be done individually, or in groups. Students need to present their ideas so that new knowledge can be derived from it.

This will encourage students to rethink what they have learned in order to come up with new ideas in order to solve a numeracy problem. After that, the students were asked to express themselves in the comments section. New ideas will emerge and these are relevant as it can help in boosting students' self-esteem as well as their understanding on the subject matter.

At this level, students will be able to identify mathematical concepts, for example in numbers, basis of calculation, measurement, shape and space as well as statistics. Moreover, students can also state the basic processes and procedures in mathematics. For example, students can state operations involved in solving a given question. Through this stage, students are able to write their initial thoughts on a given process and procedure for questions using fraction, addition etc. Besides that, students' understanding of questions and procedures will enable them to come up with new ideas about numeracy. This will provide continuity to existing knowledge after students have passed through this stage. This process helps the student develop confidence to solve a given question. It also encourages them to rethink what they have learned in order to come up with new ideas and has the ability to explain the process of getting a basic fact before solving a problem. De-coding stage enable students to illustrate and draw basic mathematical ideas. Students at this level are able to illustrate some of the key ideas of mathematics, as drawing is a pure knowledge of a person who is triggered by past experience built on advanced knowledge. It is the impression that is generated immediately (Staffe, 2009). This situation reflects the understanding of the numerical concepts of students based on what they have learnt and what they represent. Students also represent their understanding of numerical concepts in the form of diagrams. These representations are made repeatedly on the basis of their experience. For example students redefine knowledge of fractions, measurements by drawing, drawing materials and etc.

\section{Stage 2: Meaning-making}

Students at this level are able to explain how to get basic mathematical facts, for example students can explain a question that involves the basis of calculations by explaining and understanding what operations are used. In addition, students will be able to explain the processes and procedures used to solve a question and be able to match mathematical concepts after reading the given questions. Students are also able to generate their own idea during the brainstorming session, this will create relevant ideas based on their understanding. Students also learned how to get basic mathematical facts and how mathematical concepts could be understood based on the content of the given questions. At this level, students can also explain their initial thoughts, ideas and questions to understand a particular topic better. Thus, they will be able to come up with new ideas and have
Geometric shapes are known by their overall shape, which

continuity with previous thoughts on a topic once they have gone through the process. At this stage, students are also exposed on ways to obtain different data as well able to interpret and present the information accurately and accordingly. In other words, students can decide which operations to use to get answers (Anstey, 2003).

At meaning-making level, students are encourage to think about something, such as a problem, question or topic, and then voice their views. This will encourage the continuation of conceptual understanding through active arguments and explanations as students hear and share ideas, as well as encourage students to understand various perspectives. Knowledge acquisition is used when students solve numeracy problems, teachers can ask students to take time to think about a question or issue and share their thoughts with classmates. Acquiring knowledge can also be done in small groups, then formulating their ideas to the whole class.

As a result of this knowledge acquisition, students take turns presenting their own opinions, listening attentively and asking each other questions. One way to ensure that students listen to each other by telling them to explain to their peers what they understand, rather than to express their thoughts. Students will be able to anticipate how different data can be formulated more clearly and systematically. In other words, students can determine what operation will be used to get the answer. At this stage, students can match their thoughts to a problem in a question or topic and then have their own explanation. This will encourage their understanding through arguments, sharing ideas and at the same time encouraging students to understand various perspectives in solving a problem in numeracy. Students will be able to match mathematical concepts as a result of knowledge acquisition.

At this stage students can expect ways to obtain different data. When a question is given, student will be able to expect some data to be derived from the question given. Thus, students will match their thoughts to the questions posed by the topics they have followed. Here they will express their views and present ideas through a variety of perspectives in number, calculation, measurement, shape and space as well as statistics. Students will assume t types of operation to be used to solve a given question.

\section{Stage 3: Application (using)}

At this stage, students are able to complete the data obtained by making predictions, developing models and mapping concepts to solve the questions presented and considering the information or data to apply to the solution (Martin, 2008). Students can also relate the concept of numeracy to everyday life, for example the transition of time concept can be applied to the daily life of the students. Students at this level will be able to choose the appropriate procedure and use it correctly in solving questions. The students' ability to solve related questions is an indication of whether a student has mastered a concept or procedure in numeracy. At this application level students will be able to solve questions when they really understand the concept or procedure in numerical problems.

Published By:

Blue Eyes Intelligence Engineering

\& Sciences Publication

(C) Copyright: All rights reserved.

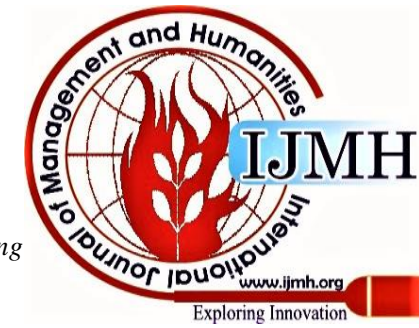


Students are able to relate the concept of numeracy into their daily lives which allow them to choose the appropriate procedure and use it appropriately in solving questions. Students' ability to solve questions is an indication of whether students can master a concept or obtain understanding in numeracy. Students can also determine the appropriateness of a principle to be used in solving new problems by providing a logical basis for the decision they make.

At this stage students are wise in determining the appropriate procedures for solving numerical comprehension and students be able to obtain important facts or concepts of numeracy that are useful in solving the questions given. From the question or text given portray students understanding ability and students apply different numerical concepts to the questions given. As a result students will apply the data by making predictions, developing models, researching, visualizing scenarios, or creating concept maps to solve the given questions and consider the information or data to apply to the given problem solving.

Students at this level are able to provide reasons or justifications for decisions made to solve new problems using the principles they follow. Students are able determine the appropriateness of a concept and principle to be used in solving a new problem by providing a rational and factual basis for a numerical concept. Students will also reiterate an old problem in order to determine principles that can be used to solve a new problem and apply different mathematical concepts to solve a given problem. At this point students are wise to consider the information or data to apply to any solution to a given problem. (Luke \& Freebody, 2009).

Study shows that students cannot apply a problem first without experiencing the process of interpreting code and acquiring knowledge (Carpenter, Moser \& Bebout, 1988). For example, students cannot solve a problem spontaneously without knowing the basic operations. This is because they often expect new problems as a result of changes in their calculation (Niemiec \& Ryan, 2009). The findings of this research show that students cannot translate numerical information properly. Therefore, students need to be trained to form a representation first before going through the application stage.

\section{Stage 4: Analyzing}

At this level, students will be able to demonstrate mathematical concepts, procedures used and be able to prove mathematical facts to support the answers provided. Students are able to determine the relationship between the evidence and the answers given, which means students can prove that each answer given is using the appropriate mathematical concepts. This includes making reasonable assumptions as well as obtaining different views from various mathematical concepts. The purpose of the analysis is to determine the thinking skills among the students, which allowed them to develop good questions in order to spark their thinking and investigate the topic. They can also describe the procedures used based on the facts and evidence provided. This will help students in brainstorming various types of questions on the topic and understand the reason given. The purpose of asking deep and interesting questions is to acquire at least the complexity and depth of a topic while also providing concrete arguments.
Therefore, through various thoughts and arguments on a given topic or question students will find various information discussed on the topic and the answers. This will produce students who are well versed in the mathematical concepts. At this stage students are able to distinguish some reasonable assumptions and encourage students to take responsibility for any evidence or argument presented. This will increase their motivation to investigate when answering a given question. At this level, students can learn a new concept or topic, this will help students to get the latest information on the topic of interest. This level of analysis can also be used during the learning session and as a way to stimulate student curiosity. Analysis can also be used when the learning session is almost over, as a way for students to demonstrate their understanding and knowledge on the subject matter. This can be achieved when students ask interesting questions and have the ability to argue. At this stage, students must be bold in deciding on a particular question or topic of learning. They must be confident to the answers given when solving a question, because they need to make sure that all the facts and concepts used in the analysis of a question are precise and accurate. They also able to prove the concepts or facts used in the solution to support the answers provided. Students are also able to determine the relationship between logical evidence, able to explain and argue about a fact or concept used to fit the answer given. Students at this stage have made the decision based on convincing evidence of a decision made. Students also believe in the mathematical or terminological concepts used and ensure that all facts and concepts are used for analysing (Grace, Evindar \& Stewart, 2003).

\section{RESEARCH OBJECTIVE}

The aim of this study is to develop and evaluate the effectiveness of edutainment based teaching and learning module in numeracy understanding among students resided in the hospital. Therefore, the objective of this study is:

1. To develop an edutainment based teaching and learning module for numeracy understanding among hospitalized students.

\section{METHODOLOGY}

There are several processes involved in the development of module. Module is produced based on findings derived from need analysis, theories, literature reviews as well as curriculum reviews. This comprehensive module then will be reviewed by four experts in the field. The appraisal is recorded in the review forms and this will be utilized for the purpose of improvement. All recommendations from these experts will be summarized in a table, as it is easier to picture parts or sections that need to be amended. The finalised module were then given to 20 evaluators which includes four experts and $16 \mathrm{MOH}$ SDH teachers to appraise and verify the accuracy of the module in terms of delivery and content.

Published By:

Blue Eyes Intelligence Engineering

\& Sciences Publication

(C) Copyright: All rights reserved.

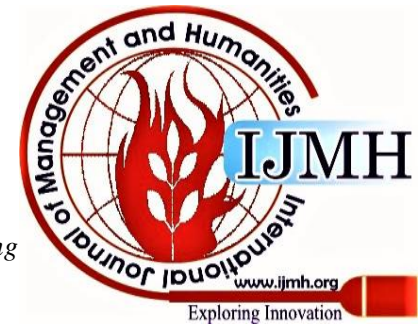


The validity of the module content was measured using content validity questionnaire which required the evaluator to provide a five-point Likert-type response: (1) strongly disagree. (2) disagree, (3) uncertain, (4) agree, (5) strongly agree. The data were analysed using the module content validation method proposed by Tuckman and Waheed (1981) which is based on Mehrabian \& Rusell's (1974) view. This method specifies that the level of proficiency or achievement of 70 percent is considered good and has mastered a high level of achievement.

\section{FINDINGS}

The development of Edutainment Based learning and teaching on numeracy understanding among hospitalized students (SDH). At the development stage, module is developed based on the findings from needs analysis, theory, literature review as well as curriculum review. Information derived from need analysis is essential in determining the types of modules needed by teachers. In order to produce a comprehensive module, these elements has to be considered namely, theory, literature review and curriculum review. Basically the contents of the module are formatted into two parts; (1) introduction and description of module usage and (2) which consists of four levels namely level 1: code interpretation, level 2: knowledge acquisition, stage 3: analysis, and level 4: application. Each level consists of 10 activities. The first part of the module contains descriptions of the stages on numeracy understanding as it also describes the levels that students required to achieve based on the activities they had performed. Once the first part has been completed, teachers can conduct activities as directed in section two. Altogether there are four levels. Each level consists of 10 activities and students need to master as well as obtain full understanding as this will determine whether they can follow or continue with other activities at second, third and fourth levels. If student has successfully passed all four levels, this indicates that the level of numeracy understanding has been achieved. The teacher's task is to guide the learning process as well as to stimulate students to think more creatively and critically. Modules that have been developed are then reviewed by four experts from different fields. Expert recommendations are collected and arranged accordingly in order to find mutual ideas. This makes it easier for researchers to identify which recommendations need to be emphasized. The results of the expert recommendation are checked to see the similarity of opinion in a particular section. Expert recommendations are shown in Table I.

Table- I: Expert Recommendations

\begin{tabular}{|c|c|c|c|c|c|}
\hline No. & $\begin{array}{c}\text { Expert } \\
\text { Recommendations } \\
(P)\end{array}$ & P1 & P2 & P3 & P4 \\
\hline 1 & $\begin{array}{ll}\text { Diversity } & \text { in } \\
\text { activities } & \end{array}$ & & & & \\
\hline 2 & $\begin{array}{l}\text { Teaching and } \\
\text { learning activities } \\
\text { need to be scheduled } \\
\text { and formatted }\end{array}$ & & & & \\
\hline 3 & $\begin{array}{l}\text { Specify the type of } \\
\text { game used }\end{array}$ & & & & \\
\hline 4 & $\begin{array}{l}\text { Learning Standard } \\
\text { should be minimised }\end{array}$ & & & & \\
\hline 5 & $\begin{array}{l}\text { The use of electronic } \\
\text { media in teaching } \\
\text { and } \\
\text { activities }\end{array}$ & & & & \\
\hline
\end{tabular}

\begin{tabular}{|c|l|l|l|l|l|}
\hline 6 & $\begin{array}{l}\text { Time of } \\
\text { Execution/Execution } \\
\text { time }\end{array}$ & & & & \\
\hline 7 & $\begin{array}{l}\text { Activities or games } \\
\text { should be } \\
\text { challenging }\end{array}$ & & & & \\
\hline 8 & $\begin{array}{l}\text { The need for peer } \\
\text { guidance in the } \\
\text { activity }\end{array}$ & & & \\
\hline
\end{tabular}

Once the module has been repaired, the module is given to experts to evaluate the accuracy as well as to determine the validity of the module content. In addition, the module was also given to 16 teachers to perform the same assessment, bringing the total content validity of the module to 20 evaluators. In terms of module delivery, 70 percent of the respondents agreed that this module is suitable for students in $\mathrm{SDH} .50$ percent said the content of the module was easy for students to follow. In terms of content, 65 per cent of reviewers found that the suggested activities are in line with the developmental level of SDH students and the procedures in conducting activities were delivered accordingly. Table II shows the analysis of the approval level of the content of the module.

Table- II: Contents Approval Level by Evaluators

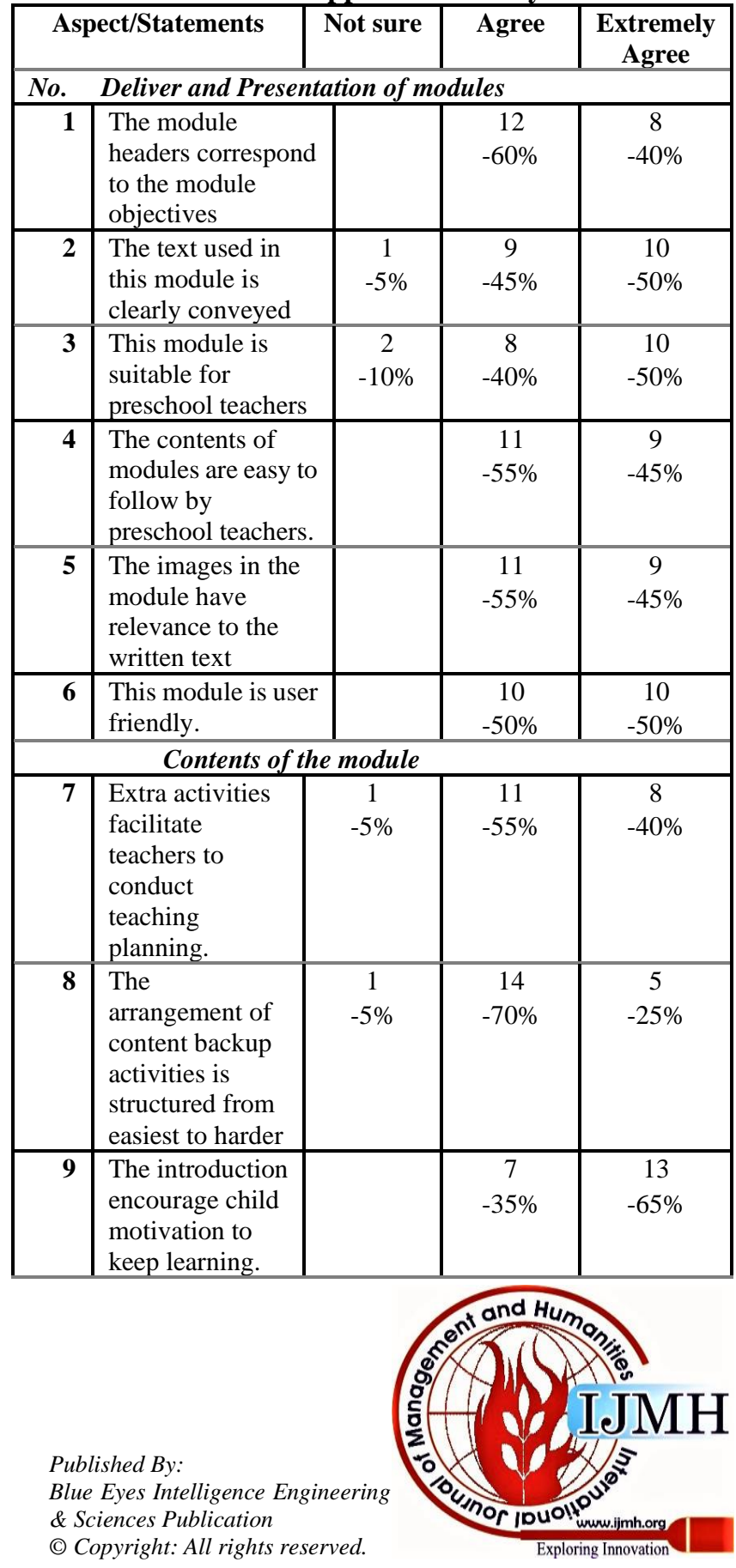




\begin{tabular}{|c|c|c|c|c|}
\hline 10 & $\begin{array}{l}\text { Reserve activity } \\
\text { seeks to improve } \\
\text { teacher } \\
\text { knowledge of } \\
\text { how to do } \\
\text { teaching. }\end{array}$ & $\begin{array}{c}2 \\
-10 \%\end{array}$ & $\begin{array}{c}7 \\
-35 \%\end{array}$ & $\begin{array}{c}11 \\
-55 \%\end{array}$ \\
\hline 11 & $\begin{array}{l}\text { Proposal of } \\
\text { activity seeks to } \\
\text { improve the } \\
\text { teacher's skills } \\
\text { for teaching. }\end{array}$ & & $\begin{array}{c}9 \\
-45 \%\end{array}$ & $\begin{array}{c}11 \\
-55 \%\end{array}$ \\
\hline \multirow[t]{2}{*}{12} & $\begin{array}{l}\text { Reserves of } \\
\text { activity seeks to } \\
\text { improve the } \\
\text { mastery of Malay } \\
\text { language skills } \\
\text { according to } \\
\text { requirements. }\end{array}$ & & 8 & 12 \\
\hline & & & $-40 \%$ & $-60 \%$ \\
\hline 13 & $\begin{array}{l}\text { Reserve activities } \\
\text { in accordance with } \\
\text { the development } \\
\text { stage of preschool } \\
\text { children. }\end{array}$ & & $\begin{array}{c}12 \\
-60 \%\end{array}$ & $\begin{array}{c}8 \\
-40 \%\end{array}$ \\
\hline 14 & $\begin{array}{l}\text { The activity steps } \\
\text { are delivered } \\
\text { regularly. }\end{array}$ & $\begin{array}{c}1 \\
-5 \%\end{array}$ & $\begin{array}{c}10 \\
-50 \%\end{array}$ & $\begin{array}{c}9 \\
-45 \%\end{array}$ \\
\hline 15 & $\begin{array}{l}\text { The proposed } \\
\text { game material is } \\
\text { interesting. }\end{array}$ & & $\begin{array}{c}9 \\
-45 \%\end{array}$ & $\begin{array}{c}11 \\
-55 \%\end{array}$ \\
\hline 16 & $\begin{array}{l}\text { The period of the } \\
\text { activity reserves } \\
\text { according to } \\
\text { activities } \\
\text { conducted. }\end{array}$ & & $\begin{array}{c}12 \\
-60 \%\end{array}$ & $\begin{array}{c}8 \\
-40 \%\end{array}$ \\
\hline 17 & $\begin{array}{l}\text { The student's work } \\
\text { sheet seeks to help } \\
\text { teachers perform } \\
\text { the enhancement } \\
\text { activities with } \\
\text { children. }\end{array}$ & & $\begin{array}{c}8 \\
-40 \%\end{array}$ & $\begin{array}{c}12 \\
-60 \%\end{array}$ \\
\hline \multirow[t]{2}{*}{18} & $\begin{array}{l}\text { The checklist } \\
\text { seeks to help } \\
\text { teachers perform } \\
\text { student } \\
\text { assessments based } \\
\text { on what has been } \\
\text { taught. }\end{array}$ & & $\begin{array}{c}7 \\
-35 \%\end{array}$ & $\begin{array}{c}13 \\
-65 \%\end{array}$ \\
\hline & Use of language & & & \\
\hline 19 & $\begin{array}{l}\text { The writing style } \\
\text { of this module is } \\
\text { easy to read. }\end{array}$ & & $\begin{array}{c}7 \\
-35 \%\end{array}$ & $\begin{array}{c}13 \\
-65 \%\end{array}$ \\
\hline 20 & $\begin{array}{l}\text { The word used in } \\
\text { the module has no } \\
\text { spelling error. }\end{array}$ & & $\begin{array}{c}11 \\
-55 \%\end{array}$ & $\begin{array}{c}9 \\
-45 \%\end{array}$ \\
\hline 21 & $\begin{array}{l}\text { The language used } \\
\text { in modules is easy } \\
\text { to understand }\end{array}$ & $\begin{array}{c}1 \\
-5 \%\end{array}$ & $\begin{array}{c}7 \\
-35 \%\end{array}$ & $\begin{array}{c}12 \\
-60 \%\end{array}$ \\
\hline 22 & $\begin{array}{l}\text { Method of writing } \\
\text { this module is } \\
\text { suitable for } \\
\text { teachers }\end{array}$ & & $\begin{array}{c}7 \\
-35 \%\end{array}$ & $\begin{array}{c}13 \\
-65 \%\end{array}$ \\
\hline
\end{tabular}

The level of content validation which has been evaluated by four experts and $16 \mathrm{SDH}$ teachers showed a percentage value above 70 percent, 90.3 percent. The findings show that this module has good content validity and meets the requirements that was specified by target audience which consists of field experts and users of the module. Table III shows the validity values of module content obtained from 20 evaluators.
Table- III: Content Validity of The Module

\begin{tabular}{|c|c|c|}
\hline Evaluator & Percentage (\%) & $\begin{array}{c}\text { Content Validity } \\
\text { Level }\end{array}$ \\
\hline 1 & 86 & Good \\
\hline 2 & 97 & Good \\
\hline 3 & 86 & Good \\
\hline 4 & 90 & Good \\
\hline 5 & 81 & Good \\
\hline 6 & 85 & Good \\
\hline 7 & 95 & Good \\
\hline 8 & 97 & Good \\
\hline 9 & 100 & Good \\
\hline 10 & 78 & Good \\
\hline 11 & 86 & Good \\
\hline 12 & 90 & Good \\
\hline 13 & 82 & Good \\
\hline 14 & 97 & Good \\
\hline 15 & 84 & Good \\
\hline 16 & 93 & Good \\
\hline 17 & 100 & Good \\
\hline 18 & 97 & Good \\
\hline 19 & 86 & Good \\
\hline 20 & 96 & Good \\
\hline $\begin{array}{l}\text { Overall Total } \\
\text { (Min) }\end{array}$ & 90.3 & Good \\
\hline
\end{tabular}

\section{DISCUSSION}

The module development process involves the process of content evaluation by both experts and users. The development of modules that are based on needs analysis, theory, literature review and curriculum review has led to the establishment of a comprehensive module.

All the information collected has contributed to the production of more knowledge-based modules. In general, this study has able to established several important points; Firstly, information derived from need analysis is essential to produce a module that can be used by teachers. Secondly, the process of module development must take into consideration on a combination of several theories in order to produce comprehensive knowledge-based modules. Thirdly, literature reviews provide important information for producing child-centered learning activities. Fourthly, curriculum reviews are also important to produce teaching and learning activities that are align with curriculum goals. Fifth, multi-field expert reviews have provided rich information both in theory and practice and finally, the evaluation of modules by both experts and users is essential in producing appropriate modules that is based on the field of study and its usage.

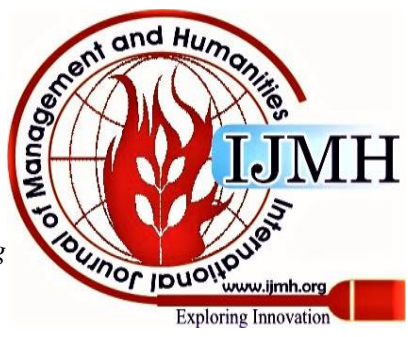




\section{CONCLUSION}

The production of teaching and learning materials at the SDH level should take into account the needs and desires of the children determination to learn. . Therefore, the development of modules at this stage should be relevant, challenging, and motivating for children to continue learning especially for children resided in the hospital. This study shows that learning activities through entertainment in this module able to provide children with meaningful learning experiences. This study in general emphasized on the production of module that is systematically arranged and this will lead to the emergence of an effective module that can be utilized to create a meaningful teaching and learning experience without teachers' guidance as a whole.

\section{LIMITATIONS AND FUTURE STUDIES}

In this study, the researcher did not focused on entire students in School for Hospitalized Children (SDH) in the process of developing and evaluating the effectiveness of module in identifying levels of numeracy understanding. So the result of this study cannot be generalized to represent the entire students in School for Hospitalized Children (SDH). The development of effective module needs to be further expanded so that learning can be nurtured from an early stage and students will enjoy learning.

\section{ACKNOWLEDGMENT}

Fundamental Research Grant Scheme (FRGS) Phase 1/2018 (research code: 2019-0033-107-02 frgs/1/2018/ss109/upsi/03/2) Hence, it is concluded that the thinking strategy on understanding numeracy among school in hospital (SDH) was successfully developed and potentially implemented in teaching and facilitating to determine the level of understanding of numeracy.

\section{REFERENCES}

1. Anstey P.R. 2003. Locke on method in natural philosophy. In: Anstey P.R. (ed.), The philosophy of John Locke: new perspectives, Routledge, London, pp. 26-42.

2. Ball, D. (2002). Mathematical proficiency for all students: Toward a strategic research and development program in mathematics education. RAND Education/Science and Teknology Policy Institute.

3. Carpenter TP, Moser JM, Bebout HC. Representation of addition and subtraction word problems. Journal for Research in Mathematics Education. 1988;19:345-357

4. Gal, I. (2002). Adult Numeracy Development:theory, research, practice. Hampton press.

5. Gerald A. Goldin .Journal for Research in Mathematics Education .Vol. 23, No. 3 (May, 1992), pp. 274-283

6. Kilpatrick, J. S. (2001). All adding it up: Helping children learn mathematics. Whingston Dc: National Academic Press.

7. Luke \& Freebody (2009). Critical numeracy.Numeracy in the news, Fakulty of Education, University of Tasmania.

8. Martin and D. Schiffer.(2008). A research companion to principles and standards for school mathematics , 68-98.

9. Mehrabian, A., \& Russell, J. A. (1974). An approach to environmental psychology. The MIT Press.

10. Niemiec, C. P., \& Ryan, R. M. (2009). Autonomy, Competence, and Relatedness in the Classroom Applying Self-Determination Theory to Educational Practice. Theory and Research in Education, 7, 133-144.

11. Noraini Idris. 2005. Pedagogi Dalam Pendidikan Matematik. Kuala Lumpur: Utusan Publications \& Distributors Sdn Bhd.

12. Ornstein, A. C. \& Hunskin, F. P. 2004. Curriculum: Foundation principles and issues.

13. Portal Rasmi Suruhanjaya Perkhidmatan Pelajaran Malaysia. Pembantu Pengurusan Murid. http://www.spp.gov.my/

14. Rivalland, J. (2000). Definitions \& identification: Who are the children with learning difficulties? Australian Journal of Learning Disabilities, 5(2), 12-16.

15. Schoenfeld Allan.H (2002). Research method in (Mathematics) education. Dlm L.D. English, M.

16. Siti Rahaimah Ali \& Noraini Idris (2014). Numerasi sekolah rendah. Perak: Universiti Pendidikan Sultan Idris.

17. Tuckman, B. W., Waheed, M. A. (1981). Evaluation an individualized science Programme for community college students. Journal of research in science teaching. 18:489-495.

18. Grace, S., Evindar, A. \& Stewart, D. (2003).The effect of postpartum depression on child cognitive development and behavior: A review and critical analysis of the literature. Arch Womens Ment Health 6, 263-274

19. Watson, J. M, Callingham, R, \& Donne, J (2008a). Establishing pedogogical content knowledge for teaching statistic, In C. Batanero, G. Burrill, C. Reading \& A. Rossman (2008), Joint ICMI/IASE Study: Teaching Statictics in School Mathematics. Proceedings of the ICMI Study 18 and 2008 IASE Round Table Conference. Monterrey: ICMI and IASE and JASE. Online:www. stat. auckland. ac nzl-iase/publications.

\section{AUTHORS PROFILE}

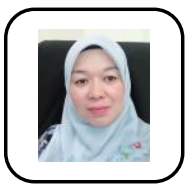

Dr. Siti Rahaimah binti Ali, is an academician in Sultan Idris Education University, Tanjong Malim, Malaysia and currently is placed at Pedagogy Department, Human Development Faculty since 2017 with 21 years of experience as an educator. On 2018, she was awarded with International Education Award from UNESCO for the commemorative work and contribution in the field of Education.and Pemenang Anugerah Distinguished Scientist in Mathematics Education-VIRA 2019). Dr Siti Rahaimah is well known in writing and publishing books and as an added bonus, one of her book has been displayed during World Book Festival at Frankfurt, German on 2013 while on December 2015, she has been chosen to represent Malaysia to participate in a course in Shanghai for 3 months. The candidate has served 10 years as an educator and another 10 years as a lecturers at the Teachers' Institute of Education and one of the responsibility held is observing or supervising the primary school teachers who are in the process of learning to become certify instructors and now dedicate themselves to the future high school teachers at Universiti Pendidikan Sultan Idris (UPSI), "College of Education No.1".

Dr Siti Rahaimah has won several awards in innovation namely gold, silver and bronze medal in the fields of Mathematics Education via The Numeracy Understanding Model that she has created in order to spark interest to learn this subject in details. She authored (and co-authored) several research papers in peer reviewed journals and conferences. She has successfully supervised Master and PhD students and also active in several clubs and societies such as (Science and Mathematics Associations), Malaysian Girl Guide and National Union of the Teacher Profession (NUTP).

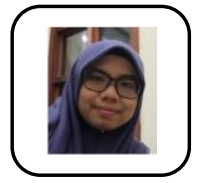

Zuria Farhana Mohamad, graduated from Sultan Abdul Halim Mu'adzam Shah International Islamic University (UniSHAMS) in Bachelor of Arabic (hons.) She is currently studies Master of Education (Primary Mathematics) from Sultan Idris Education University (UPSI) Perak, Malaysia.

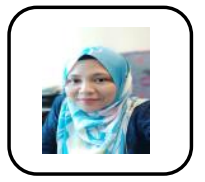

Syaza Hazwani Zaini, is a senior lecturer at Department of Educational Studies, Faculty of Human Development, Universiti Pendidikan Sultan Idris (UPSI). She received her PhD and Master of Education in the field of Educational Technology from Universiti Putra Malaysia. She already works with UPSI for nine years and research experienced are focus on instructional design, instructional materials, online learning, mobile learning and issues and trend in teaching and learning

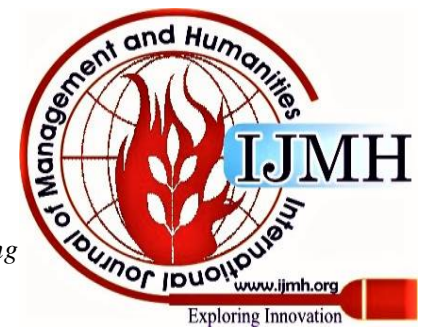


Nur Bahirah binti Badarudin, is an educator in Port Dickson Vocational College, Negeri Sembilan, Malaysia and currently is placed at Department of General Education. She received her Bachelor in the field of Educational Mathematics from Universiti Pendidikan Sultan Idris. She experienced in being a research assistance and in meantime attend a lot of education seminar. On 2019, she was awarded with MSEAM Leadership Awards in $21^{\text {st }}$ Universiti Pendidikan Sultan Idris Convocation 2019. Nur Bahirah has won two Gold medal awards in innovation (Collaboration Category in Innovation COMPEX 2019\& Innovation in Final Year Project Faculty Science and Mathematics 2019) namely in the fields of Mathematics Education via The effectiveness of Chip Mental Arithmetic Kit in Teaching and Learning in $21^{\text {st }}$ centuries for Topic Addition and Subtraction that she has collaborated with Dr Raja Noor Farah Azura binti Raja Ma'amor Shah. She co-authored of several research papers in peer reviewed journals and conferences. Nur Bahirah also also active in volunteering programme in Malaysia and Asian region. 